\title{
Synthesis and characterization of high-efficiency low-cost solar cell thin film
}

\author{
W. Christopher Immanuel ${ }^{1, *}$, S. PAul Mary DeborRah ${ }^{2}$, S.S.R. Inbanathan ${ }^{2}$, \\ D. NithyAA SREE \\ ${ }^{1}$ Department of Physics, EGS Pillay Engineering College (Autonomous), Nagapattinam, Tamil Nadu, India \\ ${ }^{2}$ Research Department of Physics American College, Madurai, Tamil Nadu, India
}

\begin{abstract}
Polycrystalline chalcogenide semiconductors play a vital role in solar cell applications due to their outstanding electrical and optical properties. Among the chalcogenide semi-conductors, CdZnS is one kind of such important material for applications in various modern solid state devices such as solar cells, light emitting diode, detector etc. Due to their applications in numerous electro-optic devices, group II-VI semiconductors have been studied extensively. In recent years, major attention has been given to the study of electrical and optical properties of $\mathrm{CdZnS}$ thin films. In this work, $\mathrm{Cd}_{1-\mathrm{x}} \mathrm{Zn}_{\mathrm{x}} \mathrm{S}$ thin films were prepared by chemical bath deposition technique. Phase purity and surface morphology properties were analyzed using field emission scanning electron microscope (FE-SEM) and X-ray diffraction (XRD) studies. Chemical composition was studied using energy dispersive spectrophotometry (EDS). Optical band gap property was investigated using UV-Spectroscopy. Electrical conductivity studies were performed by two probe method and thermoelectric power setup (TEP) to determine the type of the material. This work reports the effect of $\mathrm{Zn}$ on structural, electrical, microstructural and optical properties of these films.
\end{abstract}

Keywords: semiconductors; $C d_{1-x} Z n_{x} S$; electrodeposition; FESEM; XRD; EDS

\section{Introduction}

Sulfides of zinc and cadmium have been used successfully in various optoelectronic devices. The growth of ternary semiconductor thin films have been studied very extensively in the recent years, since these films play an important role in the fabrication of solar cells due to their favorable electrical and optical properties [1]. They are of a great technological interest in heterojunction solar cells and in photoconductive devices due to the fact that cadmium zinc sulfides $(\mathrm{CdZnS})$ thin films have a wide bandgap. The II-VI compounds due to their photoconductivity, found their use in broad applications such as photovoltaic solar energy and thin film transistor electronics [2]. Wide range of polycrystalline semiconducting materials have been studied for the photoconductivity in the visible light. Photodecay and photoresponse properties of photoconductive materials and photovoltaic structures were examined [3]. In this work an attempt has been made

*E-mail: christ.phy@gmail.com to establish the effect of $\mathrm{Zn}$ on structural, electrical, micro structural and optical properties of $\mathrm{Cd}_{1-\mathrm{x}} \mathrm{Zn}_{\mathrm{x}} \mathrm{S}$ films.

\section{Experimental}

Physical properties of electrodeposited $\mathrm{Cd}_{1-\mathrm{x}} \mathrm{Zn}_{\mathrm{x}} \mathrm{S}$ films are dependent on the deposition parameters such as the bath temperature, relative concentrations of kind of reactants in the solution, $\mathrm{pH}$ value and type of substrate. Electrodeposition technique was employed to deposit thin films of $\mathrm{Cd}_{1-\mathrm{x}} \mathrm{Zn}_{\mathrm{x}} \mathrm{S}$ on glass substrates. The starting materials, cadmium sulfate and thiourea used were of analytical grade. For the deposition of $\mathrm{Cd}_{1-\mathrm{x}} \mathrm{Zn}_{\mathrm{x}} \mathrm{S}$ thin film, a well cleaned glass substrate was immersed vertically in the solution. The temperature of bath was maintained at $70{ }^{\circ} \mathrm{C}$ for $3 \mathrm{~h}$. Triethanolamine (TEA) was used as a complexing agent. Ammonia solution was used to maintain the $\mathrm{pH}$ of the bath at 10. Finally, the coated substrates were washed with distilled water and annealed at a temperature of $225{ }^{\circ} \mathrm{C}$. The quality of thin 
films generally depends on the parameters such as deposition time and temperature of deposition. The deposition parameters employed in this study are collected in the Table 1.

\subsection{Structural properties}

\subsubsection{X-ray diffraction}

The phase purity of the film was analyzed with X-ray diffraction (Miniflex, Rigaku, Japan) using $\mathrm{CuK} \alpha$ radiation with a wavelength of $1.542 \AA$.

The structural characterization is very important for explaining structural, microstructural and electrical properties of $\mathrm{Cd}_{1-\mathrm{x}} \mathrm{Zn}_{\mathrm{x}} \mathrm{S}$ thin films. The $\mathrm{X}$-ray diffraction patterns were recorded from $20^{\circ}$ to $80^{\circ}$ as shown in Fig. 1. The XRD analysis revealed that all the films show nanocrystalline nature with cubic phase of $\mathrm{Cd}_{1-\mathrm{x}} \mathrm{Zn}_{\mathrm{x}} \mathrm{S}$. The XRD patterns confirm the formation of ternary system alloy $\mathrm{Cd}_{1-\mathrm{x}} \mathrm{Zn}_{\mathrm{x}} \mathrm{S}$ with $\mathrm{Zn}$ content $\mathrm{x}=0.2,0.4,0.6$ and 0.8 , respectively. The compositions were further confirmed using EDS analysis. The presence of sharp peaks indicates crystalline nature of the thin films, from Fig. 1. The observed peaks corre-

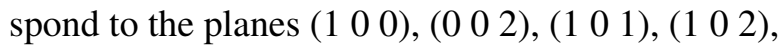
(lll 110$)$ and $\left(\begin{array}{lll}1 & 1 & 0\end{array}\right)$ which was found by matching with standard JCPDS data of CdZnS. [7]

The average crystallite size of $\mathrm{Cd}_{1-\mathrm{x}} \mathrm{Zn}_{\mathrm{x}} \mathrm{S}$ thin film samples were calculated by using the Scherrer formula:

$$
D=\frac{0.9 \lambda}{\beta \cos \theta}
$$

where, $D$ is average crystallite size, $\lambda$ is X-ray wavelength $(1.542 \AA), \beta$ is FWHM of the peak, $\theta$ is diffraction peak position. The average crystallite size of the samples is presented in Table.

\subsubsection{Field emission scanning electron micro- scope analysis}

The surface morphology of the prepared films was analyzed using a field emission scanning electron microscope coupled with energy dispersive $\mathrm{X}$-ray analysis (EDS) (FE-SEM, JEOL JED 6300).

FE-SEM images of $\mathrm{Cd}_{1-\mathrm{x}} \mathrm{Zn}_{\mathrm{x}} \mathrm{S}$ thin films are presented in Fig. 2. The FE-SEM images resolve the nanoparticles associated with the film at high

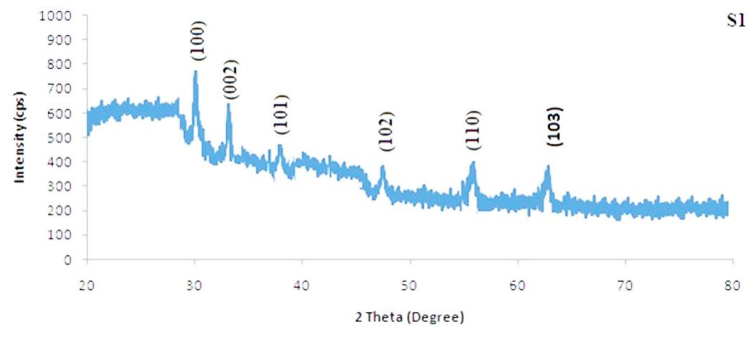

(a)

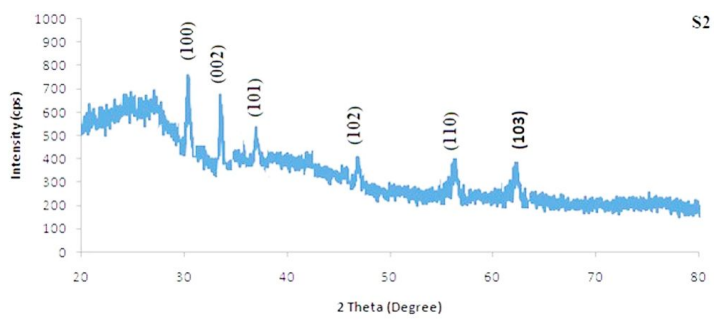

(b)

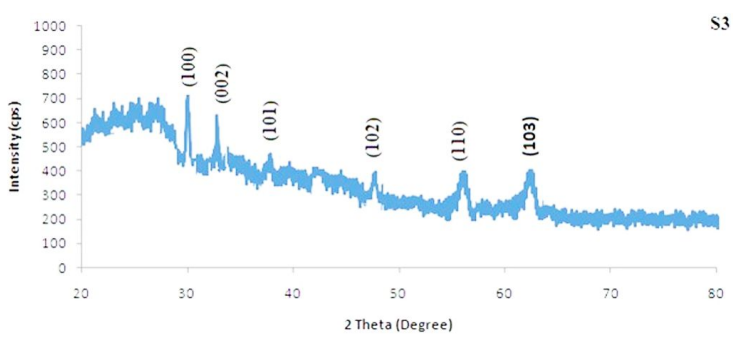

(c)

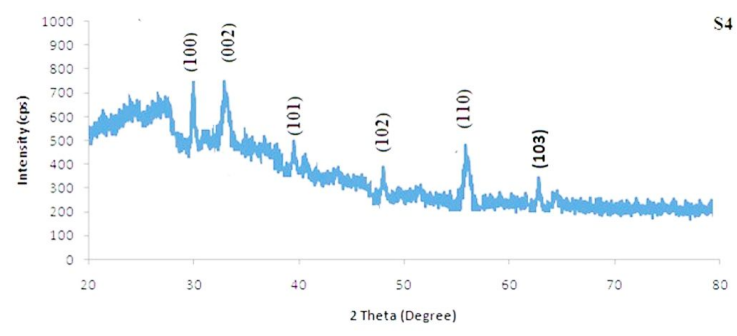

(d)

Fig. 1. X-ray diffraction patterns of $\mathrm{Cd}_{1-\mathrm{x}} \mathrm{Zn}_{\mathrm{x}} \mathrm{S}$ thin films with (a) $0.2 \% \mathrm{Zn}$, (b) $0.4 \% \mathrm{Zn}$, (c) $0.6 \%$ $\mathrm{Zn}$ and (d) $0.8 \% \mathrm{Zn}$.

magnification of $\times 15000$. Fig. 2 shows the hierarchical formation [19] of the particle for $\mathrm{Cd}_{1-\mathrm{x}} \mathrm{Zn}_{\mathrm{x}} \mathrm{S}$ thin film. Fig. $2 d$ shows agglomerations of the grains. Grain size has been tabulated in Table 3. It is observed that the grain size decreases with an increase in $\mathrm{Zn}$ content. The films show a fiber-like morphology as $\mathrm{Zn}$ content increases, which may be useful for gas sensing applications. 
Table 1. Deposition parameters of $\mathrm{Cd}_{1-\mathrm{x}} \mathrm{Zn}_{\mathrm{x}} \mathrm{S}$ thin films.

\begin{tabular}{lc}
\hline Deposition parameter & Optimum value/item \\
\hline \hline Deposition time & $70 \mathrm{~min}$ \\
$\mathrm{pH}$ & 10 \\
Concentration of precursor cadmium sulfate, & $0.1 \mathrm{M}$ \\
zinc sulfate, thiourea & Deionized water \\
Solvent & $0.2,0.4,0.6,0.8$ \\
Zn content [wt.\%] & $70{ }^{\circ} \mathrm{C}$ \\
Deposition temperature & \\
\hline
\end{tabular}

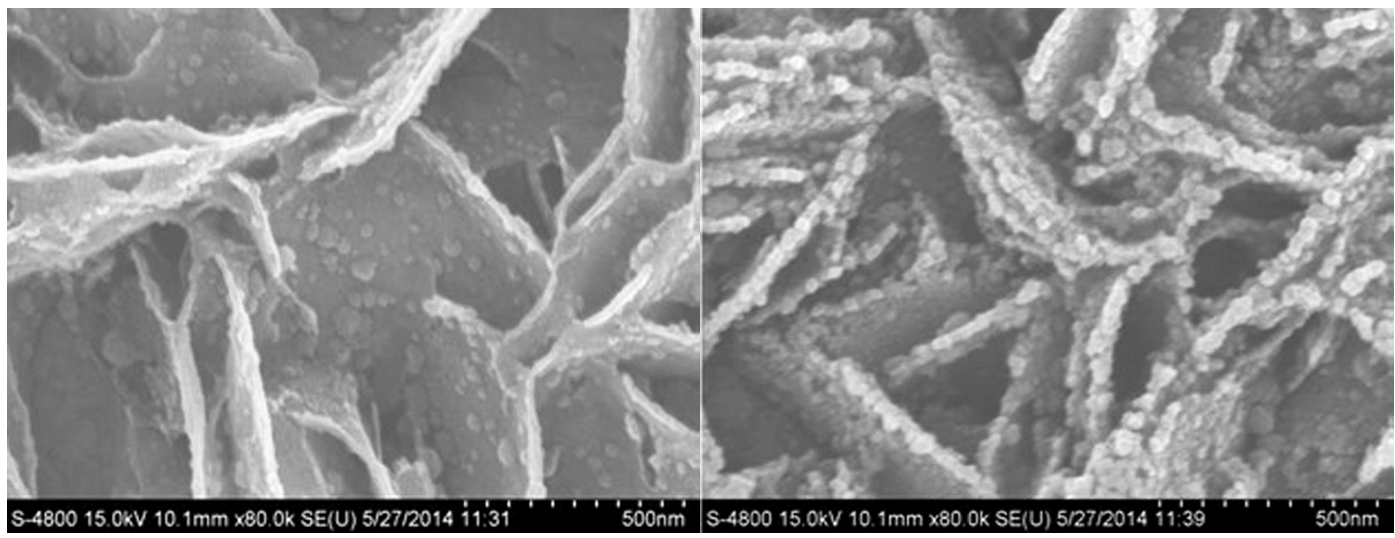

(a)

(b)

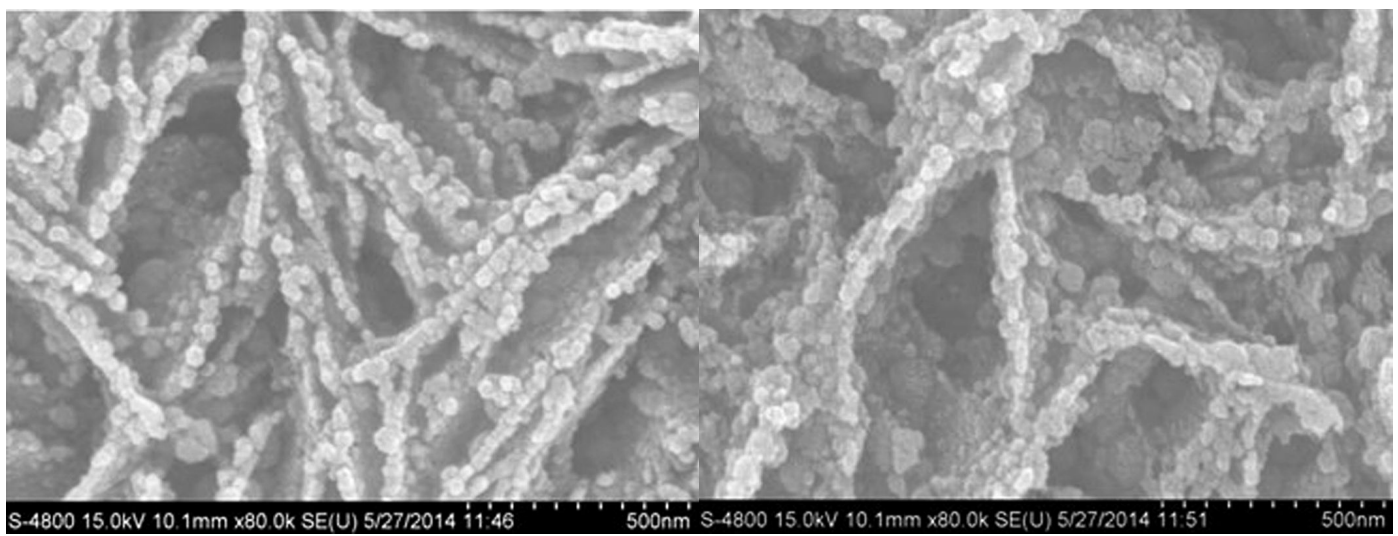

(c)

(d)

Fig. 2. FE-SEM images of $\mathrm{Cd}_{1-\mathrm{x}} \mathrm{Zn}_{\mathrm{x}} \mathrm{S}$ thin film for sample $\mathrm{S} 1$ (a), S2 (b), S3 (c) and S4 (d)

\subsubsection{Quantitative elemental analysis (EDS)}

The quantitative elemental composition of $\mathrm{Cd}_{1-\mathrm{x}} \mathrm{Zn}_{\mathrm{x}} \mathrm{S}$ thin film was analyzed using an energy dispersive spectrometer. Fig. 3 shows that the prepared $\mathrm{Cd}_{1-\mathrm{x}} \mathrm{Zn}_{\mathrm{x}} \mathrm{S}$ thin film is nonstoichiometric in nature.
Table 2 shows that $\mathrm{Cd}_{1-\mathrm{x}} \mathrm{Zn}_{\mathrm{x}} \mathrm{S}$ thin films are nonstoichiometric.

\subsection{Optical properties study using UV- spectroscopy}

Optical absorption studies of hierarchical $\mathrm{Cd}_{1-\mathrm{x}} \mathrm{Zn}_{\mathrm{x}} \mathrm{S}$ thin films were carried out in the wave- 
Table 2. Quantitative elemental analysis for as-prepared $\mathrm{Cd}_{1-\mathrm{x}} \mathrm{Zn}_{\mathrm{x}} \mathrm{S}$ thin films.

\begin{tabular}{lcccccccc}
\hline Element & \multicolumn{8}{c}{ Observed } \\
\hline & \multicolumn{2}{c}{ S1 } & \multicolumn{2}{c}{ S2 } & \multicolumn{2}{c}{ S3 } & \multicolumn{2}{c}{ S4 } \\
\cline { 2 - 9 } & wt.\% & at \% & wt.\% & at.\% & wt.\% & at.\% & wt.\% & at.\% \\
\hline \hline Cd & 40.80 & 33.65 & 46.65 & 31.87 & 48.90 & 30.68 & 47.65 & 29.88 \\
S & 18.96 & 32.80 & 14.29 & 32.44 & 15.21 & 32.89 & 13.29 & 33.61 \\
Zn & 40.24 & 33.55 & 38.66 & 35.69 & 35.89 & 36.43 & 39.06 & 36.51 \\
Total & 100.00 & 100.00 & 100.00 & 100.00 & 100.00 & 100.00 & 100.00 & 100.00 \\
\hline
\end{tabular}

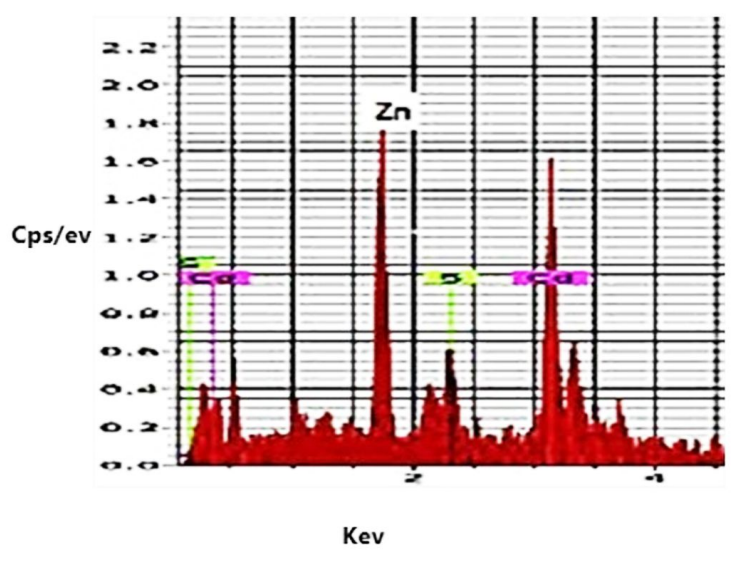

Fig. 3. EDAX of $\mathrm{Cd}_{1-x} \mathrm{Zn}_{\mathrm{x}} \mathrm{S}$ thin film sample (S3).

length $\lambda$ range of $300 \mathrm{~nm}$ to $600 \mathrm{~nm}$ at room temperature, using UV-Vis-2450 spectrophotometer. The change in absorbance with the wavelength $\lambda$ is shown in Fig. 4. The band gap energies of the samples were calculated from the absorption edges of the spectra [8].

The slope drawn from the start of an absorption edge (the onset of absorbance) and horizontal tangent drawn on absorption minimum intercept each other at some point shown in Fig. 4. The effect of $\mathrm{Zn}$ content on the band gap Eg value of the $\mathrm{Cd}_{1-\mathrm{x}} \mathrm{Zn}_{\mathrm{x}} \mathrm{S}$ films have been studied. To obtain the band gap value, the absorption coefficient $\alpha$ was calculated from the absorption data. Optical band gap energies of the samples were observed to be slightly varying from $3.55 \mathrm{eV}$ to $3.71 \mathrm{eV}$ [9]. It is well known that a momentous increase in the band gap energy is possible when the size of crystallites reaches the size of the quantum dots. It can be seen

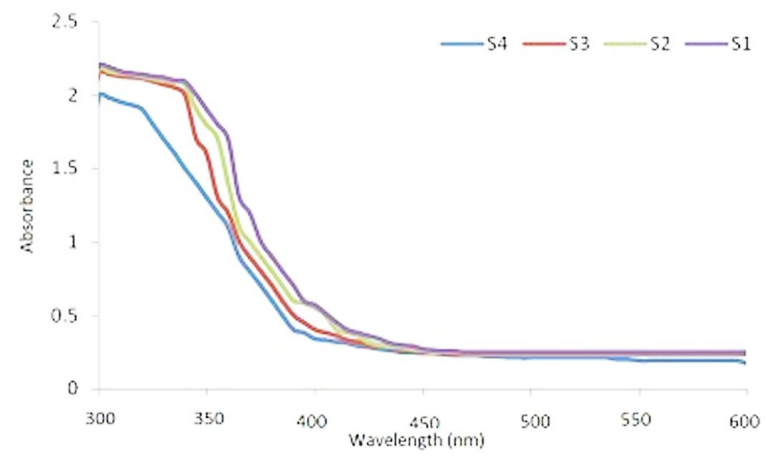

Fig. 4. Variation of absorbance with the wavelength for samples S1, S2, S3 and S4.

that the band gap varies with $\mathrm{Zn}$ content in a nonlinear way [13].

\subsection{Variation of crystallite size, grain size and dislocation density with $\mathrm{Zn}$ content}

The details of the composition and calculated crystal sizes varying with $\mathrm{Zn}$ content are given in Table 3. It is clear from Table 3, that the grain size decreases from $39 \mathrm{~nm}$ to $31 \mathrm{~nm}$ with an increase in $\mathrm{Zn}$ content in the thin films and optical band gap energy increases with an increase in $\mathrm{Zn}$ content $[4,8-10]$. This may be due to the enhancement in the crystallinity with an increase in $\mathrm{Zn}$ content which leads to minimum imperfection. A slight increase in the optical band gap energy of the films with increasing $\mathrm{Zn}$ percentage can be attributed to the increase in the crystallite and grain size. 
Table 3. Details of $\% \mathrm{Zn}$ content in $\mathrm{Cd}_{1-\mathrm{x}} \mathrm{Zn}_{\mathrm{x}} \mathrm{S}$ thin film, crystallite size, grain size and optical band gap energy.

\begin{tabular}{ccccc}
\hline Sample No. & $\begin{array}{l}\text { Zn } \\
\text { content }\end{array}$ & $\begin{array}{l}\text { Average } \\
\text { crystallite } \\
\text { size from } \\
\text { XRD [nm] }\end{array}$ & $\begin{array}{l}\text { Average grain } \\
\text { size from } \\
\text { FE-SEM [nm] }\end{array}$ & Optical band gap from UV-Vis [eV] \\
\hline \hline S1 & 0.2 & 26 & 39 & 3.55 \\
S2 & 0.4 & 22 & 36 & 3.61 \\
S3 & 0.6 & 20 & 33 & 3.69 \\
S4 & 0.8 & 17 & 31 & 3.71 \\
\hline
\end{tabular}

\section{Electrical properties}

\subsection{Thermoelectric power measurements}

The p-type or n-type conductivity of $\mathrm{Cd}_{1-\mathrm{x}} \mathrm{Zn}_{\mathrm{x}} \mathrm{S}$ thin films was confirmed by measuring the thermoelectric power of the thin film samples. The thermoelectric power TEP was measured as a function of temperature in the range between $320 \mathrm{~K}$ and $400 \mathrm{~K}$.

For $\mathrm{Cd}_{1-\mathrm{x}} \mathrm{Zn}_{\mathrm{x}} \mathrm{S}$ material, conduction electrons also originate from ionized defects such as oxygen vacancies, rendering n-type conductivity apart from free electrons available. The variation of the thermo emf with temperature difference for all the samples is shown in Fig. 6. TEP increases with an increase in temperature for all samples. $\mathrm{Cd}_{1-\mathrm{x}} \mathrm{Zn}_{\mathrm{x}} \mathrm{S}$ thin films were observed to be the n-type material.

\subsection{Electrical conductivity}

Fig. 7 shows the variation of $\log \sigma$ with $1 / T$. The conductivity of each sample is observed to increase with an increase in temperature. The rise in conductivity with an increase in temperature implies negative temperature coefficient of resistance and semiconducting nature of $\mathrm{Cd}_{1-\mathrm{x}} \mathrm{Zn}_{\mathrm{x}} \mathrm{S}$ thin films. The electrical conductivity of the film decreases with an increase of $\mathrm{Zn}$ content. The decrease in electrical conductivity may be attributed to the effect of grain size. The grain size of the film decreases with increasing $\mathrm{Zn}$ percentage [11].

\subsection{I-V characteristics of thin film of $\mathbf{C d}_{1-x} \mathbf{Z n} \mathbf{n}_{x} \mathbf{S}$ thin films}

Fig. 8a depicts the I-V characteristics of $\mathrm{Cd}_{1-\mathrm{x}} \mathrm{ZnxS}$ thin film which is slightly exponential in nature. The I-V characteristics for some samples show that the dark current is negligible, while the current under illumination increases linearly upon increasing the intensity of the light. The contact is ohmic in nature and reveals semiconducting nature of the films.

The variation of photocurrent of $\mathrm{Cd}_{1-\mathrm{x}} \mathrm{Zn}_{\mathrm{x}} \mathrm{S}$ thin films with applied voltage is shown in Fig. 8 b. The plot shows that there is a linear dependence of photocurrent with applied voltages. The measurement results were analyzed and exposed regions exhibit ohmic conduction mechanism.

Average value of dark resistance is $485 \mathrm{M} \Omega$ and it deceases to $100 \mathrm{M} \Omega$, when light is incident on $\mathrm{Cd}_{1-\mathrm{x}} \mathrm{Zn}_{\mathrm{x}} \mathrm{S}$ thin film. The $\mathrm{Cd}_{1-\mathrm{x}} \mathrm{Zn}_{\mathrm{x}} \mathrm{S}$ films have the highest conductivity for $0.2 \% \mathrm{Zn}$ content compared to other compositions.

\subsection{Measurement of photoconductivity as a function of wavelength}

A plot of photocurrent vs. wavelength of light is shown in Fig. 9. The photocurrent increases with wavelength, reaches a maximum and then decreases. The maximum photoconductivity is observed around $500 \mathrm{~nm}$ which corresponds to the band gap of thin films. The photoresponse is observed to decrease both on shorter and longer wavelength side. The decreasing photoresponse on the shorter wavelength side may be due to the surface recombination states. The decrease in photoresponse in long wavelength region is due to cationic vacancies. As the population of these defect levels goes on decreasing above the valence band, the photocurrent decreases with a decrease in energy of the illuminating light [18]. It is seen that for 


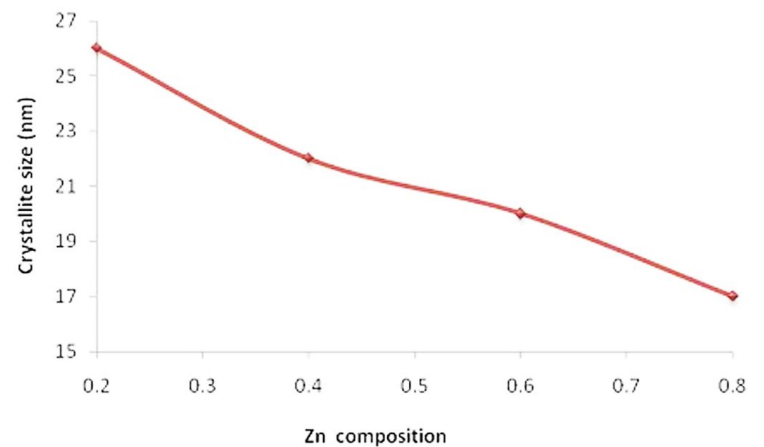

(a)

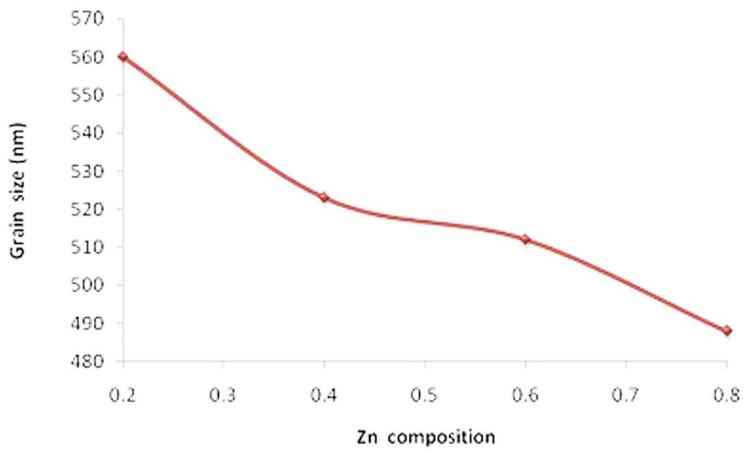

(b)

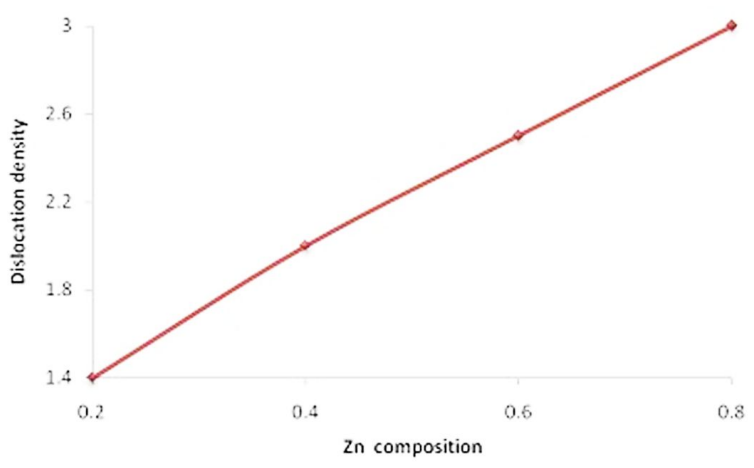

(c)

Fig. 5. (a) Variation of crystallite size with Zn content; (b) variation of grain size with $\mathrm{Zn}$ content; (c) variation of dislocation density with $\mathrm{Zn}$ content.

lower intensity of light, the slope of the graph is less than unity showing a sublinear behavior which clearly indicates that the photoconductivity of the films is defect controlled. The photosensitivity of $\mathrm{Cd}_{1-\mathrm{x}} \mathrm{Zn}_{\mathrm{x}} \mathrm{S}$ is dependent on the wavelength of the incident light.

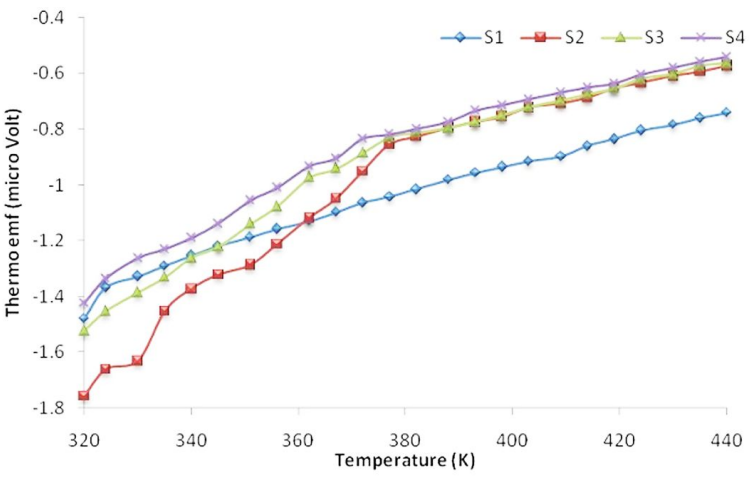

Fig. 6. Variation of the thermo emf with temperature.

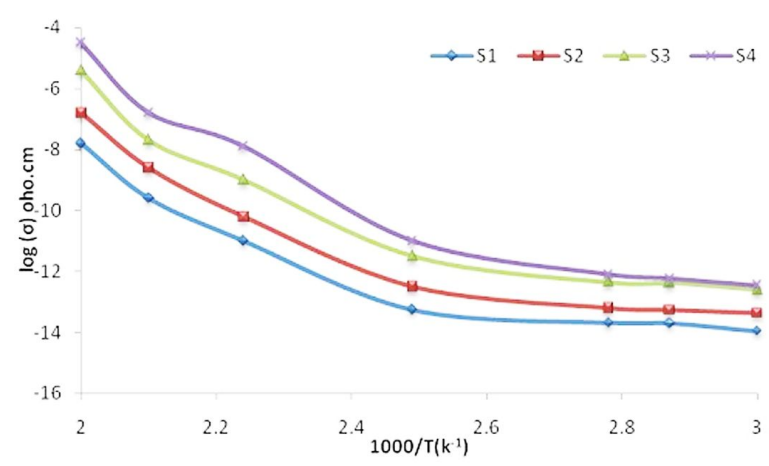

Fig. 7. Temperature dependence of $\mathrm{Cd}_{1-\mathrm{x}} \mathrm{Zn}_{\mathrm{x}} \mathrm{S}$ conductivity.

\subsection{Measurement of photoconductivity as a function of distance from the light source for different applied voltages}

The variation of photocurrent of $\mathrm{Cd}_{1-\mathrm{x}} \mathrm{Zn}_{\mathrm{x}} \mathrm{S}$ thin films with varying applied voltage is shown in Fig. 10. The plot shows linear dependence on different distances with different applied voltages.

\subsection{Measurement of photoconductivity as a function of distance from light source}

From Fig. 11 it is observed that the photocurrent decreases as the intensity of light decreases with increasing distance between the light source and the conductor. It is also observed that the photocurrent is higher in case of blue light than green source of light. 


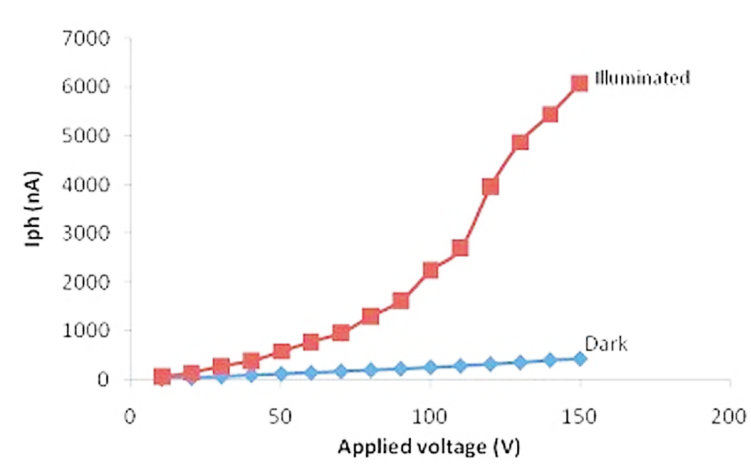

(a)

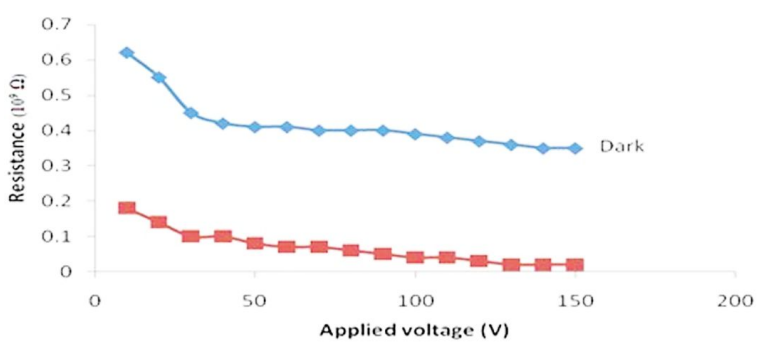

(b)

Fig. 8. (a) I-V characteristics of the films; (b) resistance vs. applied voltage for dark and illuminated films.

\subsection{Measurement of resistance as a func- tion of illuminance}

Fig. 12a gives a typical example of $\mathrm{Cd}_{1-\mathrm{x}} \mathrm{Zn}_{\mathrm{x}} \mathrm{S}$ thin film as a function of incident light. The slope $\mathrm{dR} / \mathrm{d} \theta$ of the curve varies. It is important for detecting anolog-like light level differences. It is seen that for lower intensity of light, the slope is less than unity, showing a sublinear behavior which clearly indicates that the photoconductivity of the films is defect controlled [13-17].

\section{Conclusions}

The following conclusions are derived from the reported work on effect of $\mathrm{Zn}$ percentage on the properties of $\mathrm{Cd}_{1-x} \mathrm{Zn}_{\mathrm{x}} \mathrm{S}$ thin films obtained by electrodeposition technique.

1. The crystallite sizes for $\mathrm{Cd}_{1-\mathrm{x}} \mathrm{Zn}_{\mathrm{x}} \mathrm{S}$ films are found to range from $31 \mathrm{~nm}$ to $39 \mathrm{~nm}$.

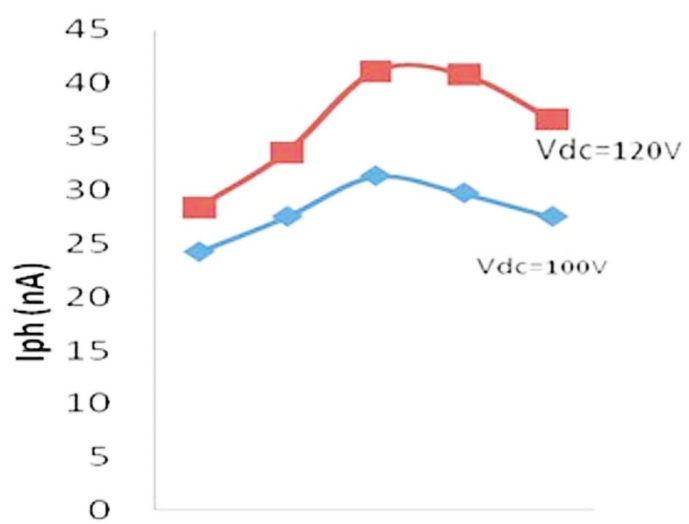

420470500530620

$\lambda(\mathrm{nm})$

Fig. 9. Photocurrent $I_{P h}$ vs. wavelength characteristics.

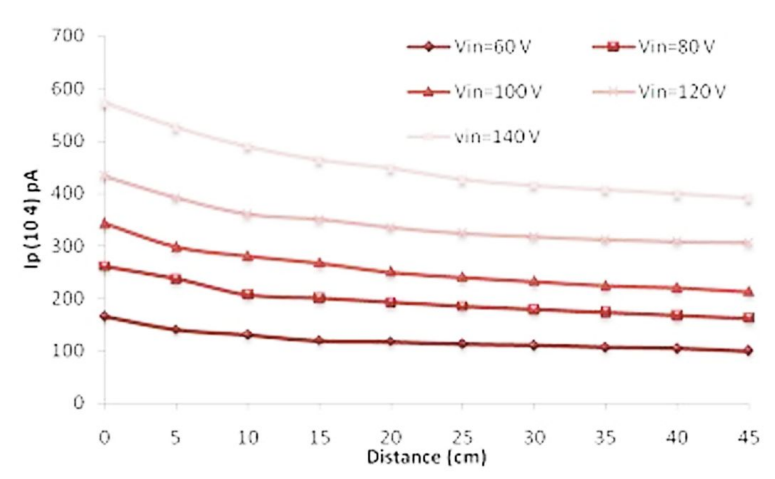

Fig. 10. Variation of photocurrent $\mathrm{I}_{\mathrm{ph}}$ for $\mathrm{Cd}_{1-\mathrm{x}} \mathrm{Zn}_{\mathrm{x}} \mathrm{S}$ thin film with distance from the light source, at different applied voltages.

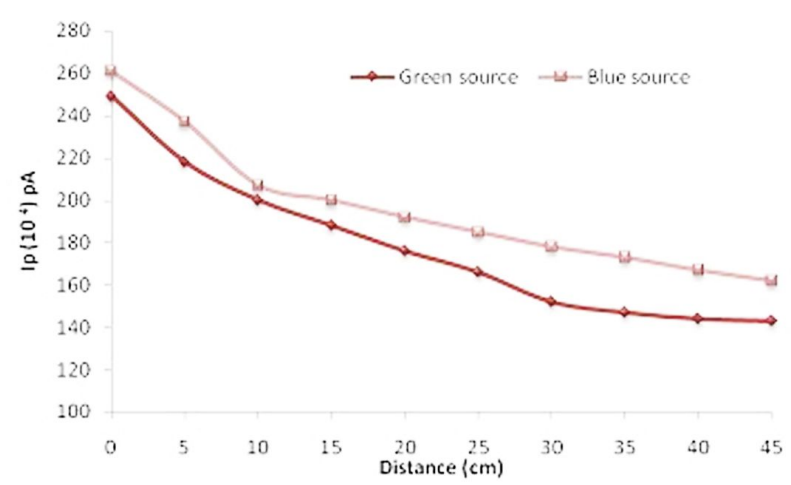

Fig. 11. Photocurrent $\mathrm{I}_{\mathrm{ph}}$ of $\mathrm{Cd}_{1-\mathrm{x}} \mathrm{Zn}_{\mathrm{x}} \mathrm{S}$ thin film vs. distance from different sources of light 


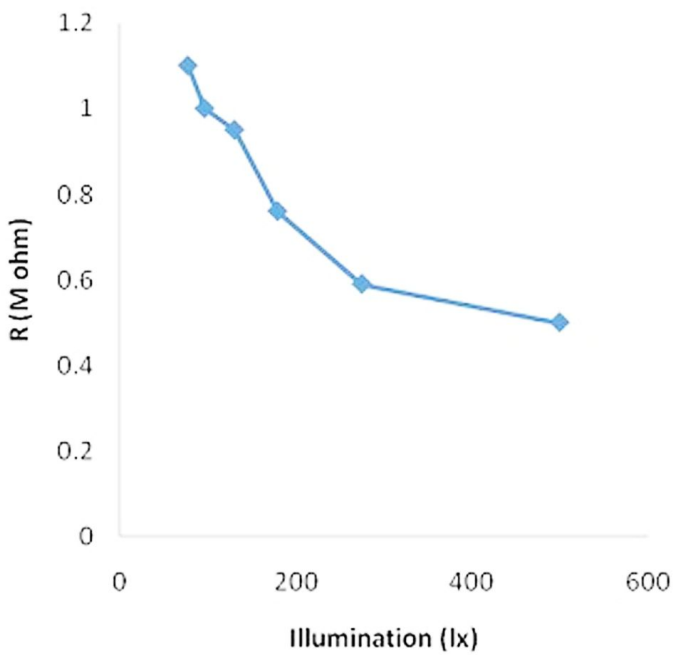

(a)

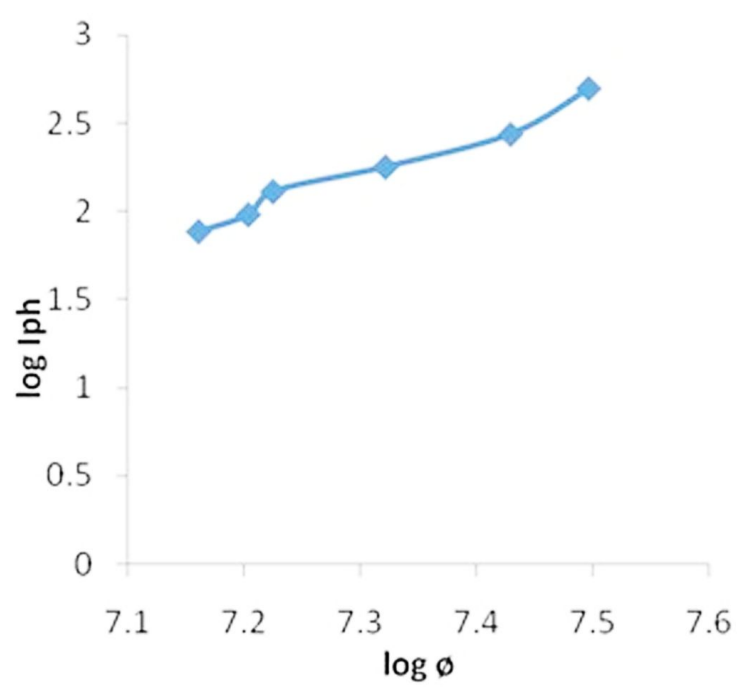

(b)

Fig. 12. (a) Resistance vs. illuminance curve; (b) photocurrent $\mathrm{I}_{\mathrm{ph}}$ vs. light intensity $\theta$ characteristics.

2. The chosen deposition parameters produced $\mathrm{Cd}_{1-\mathrm{x}} \mathrm{Zn}_{\mathrm{x}} \mathrm{S}$ thin films of good homogeneity, with varying $\mathrm{Zn}$ percentage.

3. The peak analysis from the XRD patterns showed formation of $\mathrm{Cd}_{1-\mathrm{x}} \mathrm{Zn}_{\mathrm{x}} \mathrm{S}$ thin films, confirmed by EDS data.

4. The study suggests that the increase in $\mathrm{Zn}$ percentage in the film leads to an increase in crystallite size, grain size and optical band gap.
5. Morphological studies of the films confirmed that the as-prepared $\mathrm{Cd}_{1-x} \mathrm{Zn}_{\mathrm{x}} \mathrm{S}$ thin films are composed of hierarchical rod-like structure. The films also reveal fiber-like structure as $\mathrm{Zn}$ content increased, which may be useful for gas sensing applications.

6. The elemental analysis confirmed that the as-prepared $\mathrm{Cd}_{1-\mathrm{x}} \mathrm{Zn}_{\mathrm{x}} \mathrm{S}$ thin films are nonstoichiometric in nature.

7. Electrical conductivity increased with an increase in temperature of the $\mathrm{Cd}_{1-\mathrm{x}} \mathrm{Zn}_{\mathrm{x}} \mathrm{S}$ thin films, indicating their semiconducting nature.

8. TEP measurement indicated that the asprepared $\mathrm{Cd}_{1-\mathrm{x}} \mathrm{Zn}_{\mathrm{x}} \mathrm{S}$ thin films are of $n$ type.

9. All samples exhibit photoconductive effect when excited by a light source. The $\mathrm{Cd}_{1-\mathrm{x}} \mathrm{Zn}_{\mathrm{x}} \mathrm{S}$ photoconductor behaves like an ohmic resistance that depends upon the intensity of source light. These results will have a significant impact on the use of $\mathrm{Cd}_{1-\mathrm{x}} \mathrm{Zn}_{\mathrm{x}} \mathrm{S}$ semiconductors in optoelectronics devices.

\section{References}

[1] Tyan Y.S., Sol. Cell., 23 (1988), 59.

[2] Shashibhusha N., Chandr T.A., Turk. J. Phys., 32 (2008), 21.

[3] Pisarkiewicz T., Opto-Electron. Rev., 12 (2004), 33.

[4] Celalattinbaybul M., Nilgunortha N., Thin Solid Films, 518 (2010) 1925.

[5] Nagamani K., Reddy M.V., Lingappa Y., RaMAKRISHNA K.T., REDDY R., Miles W., Int. J. OptoElectron. Eng., 2(2012), 1.

[6] Clemminck I., Burgelman M., Casteleyn M., DEPUYDT B., Int. J. Solar Energ., 12 (1992), 67.

[7] Singh S., Shrivastava A.K., Int. J. Innov. Res. Sci. Eng. T., 3 (2014), 1.

[8] Sanap V.B., PAWAR B.H., J. Opto-Electron. Biomed. Mat., 2 (2011), 39.

[9] Sharma T.P., PATIDAR D., SAXENA M.S., Sharma K., Indian J. Pure Appl. Phys., 44 (2006), 125.

[10] Selma M.H., JaWAd A., Eng. Tech. J., 31 (2013), 1.

[11] Mahdi M.A., J. Basrah Res., 35 (2009), 1.

[12] Li W., Yang J., Sun Z., Feng L.-H., Zhang J.-Q., WU L., Int. J. Photoenerg., 214 (2011), 5.

[13] Kawar S.S., Hurde K.K., PachKawade A.P., PAWAR B.H., Int. J. Basic Appl. Res., 5 (2012), 157. 
[14] Sharma T.P., Patidar D., SAXENA M.S., Sharma K., Indian J. Pure Appl. Phys., 44 (2006), 125.

[15] Borase S.V., Chavan S.D., Sharma R., J. Alloy. Compd., 436 (2007), 501.

[16] RaVangave L.S., Biradar U.V., Misal S.D., Glob. Res. Anal., 2 (2013), 1.

[17] Mosiori C.O., Nuoroge W., Nandokumu J., Dir. Res. J. Chem. Mat. Sci., 2 (2014), 13.

[18] Patil R.H., Patil S.N., Nikam S.V., LAdGaOnKaR B.P., Int. J. Adv. Eng. Technol., 6 (2013), 688.
[19] Ubale A.U., Chipade K.S., Bhute M.V., Raut P.P., MalPe G.P., Sakhare Y.S., BelkhedKar M.R., Int. J. Mater. Chem., 2 (2012), 165.

[20] Sandhyapilla I., Bhushanb S., Proc. Nano Thailand, 2012.

Received 2018-07-19

Accepted 2019-01-09 